\title{
sciendo
}

\section{Contributions of social entrepreneurship to textile waste prevention in Romania}

\author{
Daniela STAICU \\ The Bucharest University of Economic Studies, The Doctoral School for Business \\ Administration, Bucharest, Romania \\ Danielastaicu@gmail.com
}

\begin{abstract}
The current system for producing, distributing, and using clothing is putting pressure on resources, pollutes and degrades ecosystems. Nowadays, when disposed of, clothing still has at least $70 \%$ of its useful life left. A different approach to the way clothes are made, distributed and disposed of is needed. Prevention of textile waste is one angle to address these challenges and is being taken into consideration by the European public bodies. Reuse is increasingly recognized as a waste prevention measure, specifically addressed in 25 of the 33 waste prevention programs of European countries but national approaches to encourage reuse are, so far weak. Though in Romania it is estimated that textile waste will be produced mainly by households by 2025, knowledge about clothing reuse stakeholders and the mechanisms of exchange is scarce. Some activity is however developed by charities, acting as social enterprises. The primary goal of this research was to understand the role of social entrepreneurship in textile waste prevention by identifying clothing reuse practices and stakeholders in Bucharest, the Romanian city with the largest number of households in Romania (10\% of the total of households). By gaining concrete knowledge related to the clothing reuse initiatives, in terms of number and characteristics, moving from identifying current clothing reuse practices and mechanisms of exchange to the type of stakeholders involved, either public or private, the research contributed to modeling the circular business ecosystem in Romania. The main research question concerned the degree of involvement of social enterprises in the development of clothing reuse activities, and therefore textile waste prevention. The findings revealed a high disproportion between the number of private and public clothing reuse initiatives, most of the activities being developed by charities which to some extent act as social enterprises. The results were intended to provide information to support decision-making bodies and communities in building up a functional clothing waste prevention plan through benefiting of existing knowledge from stakeholders in the field. These results also open the pathway to public-private dialogue for highlighting and scaling up existing textile waste prevention activities.
\end{abstract}

Keywords: textile waste prevention, clothing reuse, social entrepreneurship, textile waste, waste management.

\section{Introduction}

The current system for producing, distributing, and using clothing operates on a model which is putting pressure on resources, pollutes and degrades ecosystems (Ellen MacArthur Foundation, 2017). In the last 15 years, clothing production has doubled and more than half of fashion produced is disposed of in under a year (Ellen MacArthur Foundation, 2017; Farrant et al., 2010) even though it still has at least $70 \%$ of its useful life left when disposed of (Woolridge et al., 2006). Because of the aforementioned challenges, a new approach to the way clothes are made, distributed and disposed of is needed. Prevention of textile waste is one angle to address these challenges (Tojo et al., 2012). Whereas in the European Union, there is regulatory interest in increasing prevention of textile waste through textile reuse and recycling (European Commission, 2010), Romanian authorities do not have a plan in place for textile waste prevention, though $1 \%$ of the waste will be generated by mainly by households' textiles by 2025 (Ministerul Mediului, 2018). However, various actions 
related to textile waste prevention are carried out by private stakeholders, among them charity organizations are mainly in charge of collecting reusable textile products (Tojo et al., 2012).

The primary goal of this research was to understand the role of social entrepreneurship in clothing reuse practices in Bucharest by gaining concrete knowledge related to the stakeholders in household clothing reuse initiatives practiced in Bucharest, in terms of number and characteristics, moving from identifying current clothing reuse practices and mechanisms of exchange to the type of stakeholders involved: public or private. Bucharest was chosen for this research because it has 770535 households, the largest number in Romania (10\% of the total of households). Any model of stakeholder analysis developed for Bucharest can be consequently used for mapping the stakeholders and practices in clothing reuse in other cities. To achieve the goal, qualitative content analysis was carried out and the following objectives were established: (1) to identify practices and stakeholders related to clothing reuse in the international scientific body of literature; (2) to recognize practices and stakeholders related to clothing reuse in the Romanian scientific body of literature, based on the results collected from the international body of literature; (3) to classify clothing reuse practices and stakeholders according to ownership: public or private, mechanism of exchange, and type of business; (4) to determine which of the two sectors, public or private have developed more initiatives and what role do social entrepreneurs play.

The main research question is "Are social entrepreneurs the main driver of textile waste prevention through clothing reuse activities in Bucharest?". To validate the research question, two assumptions were formulated:

A1: In Bucharest, both private and public stakeholders are involved in clothing reuse practices.

A2: In Bucharest, charities acting as social enterprises are the main stakeholders in clothing reuse practices.

The current research entailed: searching the scientific body of literature for clothing reuse definitions and practices; developing a database with clothing reuse practices of private and public stakeholders in Bucharest; classifying the mechanisms of exchange between households and stakeholders; identifying data gaps, future research needs and formulating recommendations.

The research contributes to modeling the circular business ecosystem for textiles in Romania through offering a method to identify the players in the textile waste management sector. The results were intended to provide information to support decision-making bodies and communities in building up a functional clothing waste prevention plan through benefiting of existing knowledge from stakeholders in the field. These results also open the pathway to public-private dialogue for highlighting and scaling up existing textile waste prevention activities.

\section{Literature review}

Textile and clothing production is a major component of the European manufacturing industry (Resta et al., 2016) and accounts for a 3\% share of the value-added goods and a 6\% share of the employment (Euratex, 2017). The global demand for textile products is steadily increasing (Smith et al., 2017; The Fiber Year Consulting, 2015), a trend likely to continue because of rising population, economic development and fast fashion understood as offering new products to the market as fast as possible (Cuc and Tripa, 2014). Economic growth began to depend on the ongoing promotion of new products and the disposal of old ones, which were branded useless simply because the stylistic norms emphasized their obsolescence (Claudio, 2007). Today clothes are made to be used for a comparatively short time, likely to be discarded after just seven or eight wears (Koszewska, 2018), about half as long as they did 15 years ago (Remy et al., 2016), as the ubiquitous linear models of consumption dictate 
(Durham, 2015), value being lost in use. A negative consequence of these consumption patterns is that the opportunities for reuse of low-value clothing at the end of its useful life are few, if it quickly goes out of fashion, or has poor appearance retention, dimensional stability, or durability (Durham et al., 2015). Moreover, the clothing industry is subject to severe ecological and social problems in most of the phases of the supply chain spanning from fiber production, spinning, fabric production, dyeing and finishing, to clothing production (Goldbach and Seuring, 2003; Lenzing, 2017; Shen et al., 2010). In the world regions, textiles and clothing waste comprises between 1 and $5.1 \%$ of municipal solid waste compositions and has become a universal concern (Pipatti et al., 2006). In Romania, textile waste is estimated to reach $1 \%$ of the total municipal waste by 2025 and to be generated mainly by households (Ministerul Mediului, 2018).

Conventional methods of dealing with issues of waste, sustainability, and resource efficiencies have not addressed continuous and rising consumption levels (Smith et al, 2017) nor have developed an overall vision to achieve sustainability (Martin, 2013). The circular economy model (figure 1), restorative and regenerative by intention is gaining more and more attention by promoting the use and reuse of natural capital as efficiently as possible, and by finding value throughout products' life cycles (Koszewska, 2018).

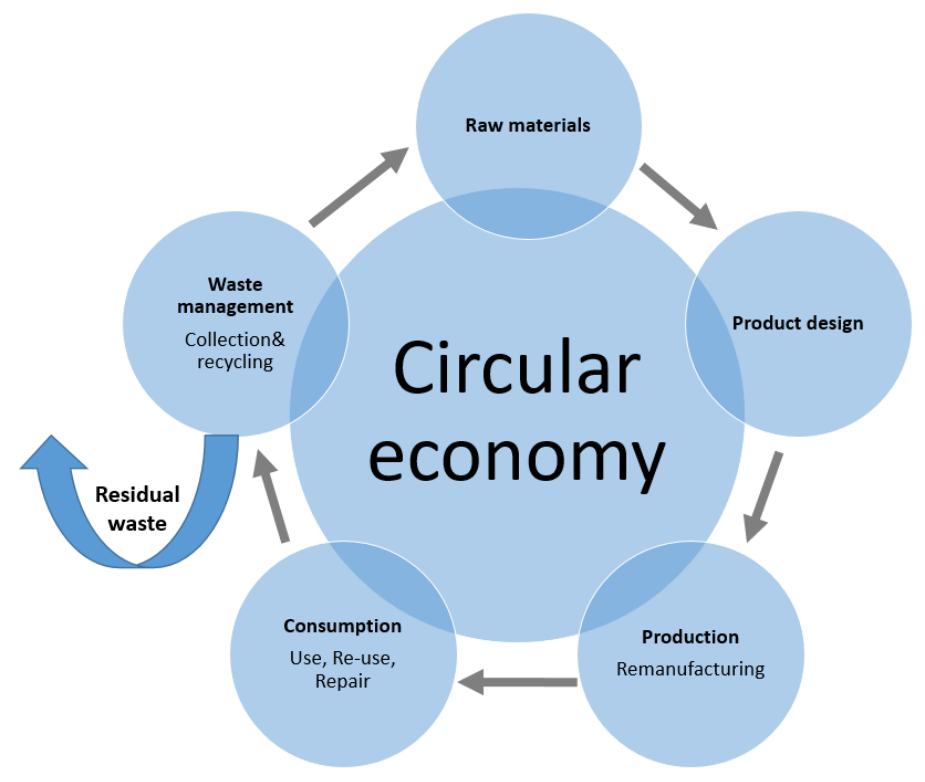

Figure 1. Circular economy framework

Source: Authors' own processing based on www.urbact.eu

To move towards this new model, we need to re-imagine production and consumption systems and develop ways to educate designers and consumers to a more circular way of thinking (Smith et al., 2017). Such transition requires a combination of different measures for impact reduction, most likely including more reuse (Farrant et al., 2010) and recycling. The European Union recognizes the need to reduce the quantity of materials we consume and dispose of (European Union, 2010) and prioritizes practices ranging from waste prevention to landfill (Van Ewijk and Stegemann, 2016). The goal to divert waste from the landfill is to disrupt the current production processes and waste management behaviors, by reducing waste based on the time it occurs: produced during the manufacturing process, discarded by consumers or generated from industrial applications (Leonas, 2017).

One principle in the circular economy for textile is to reuse end-of-life clothing, which, in addition to being worn again, can also be cascaded down to other industries to make insulation or stuffing or simply recycled into yarn to make fabrics that save virgin fibers 
(figure 2), but recycling is the last value cycle after other measures (inner value cycles) to restore and regenerate value with minimum environmental impact are taken (Fontell and Heikkilä, 2017).

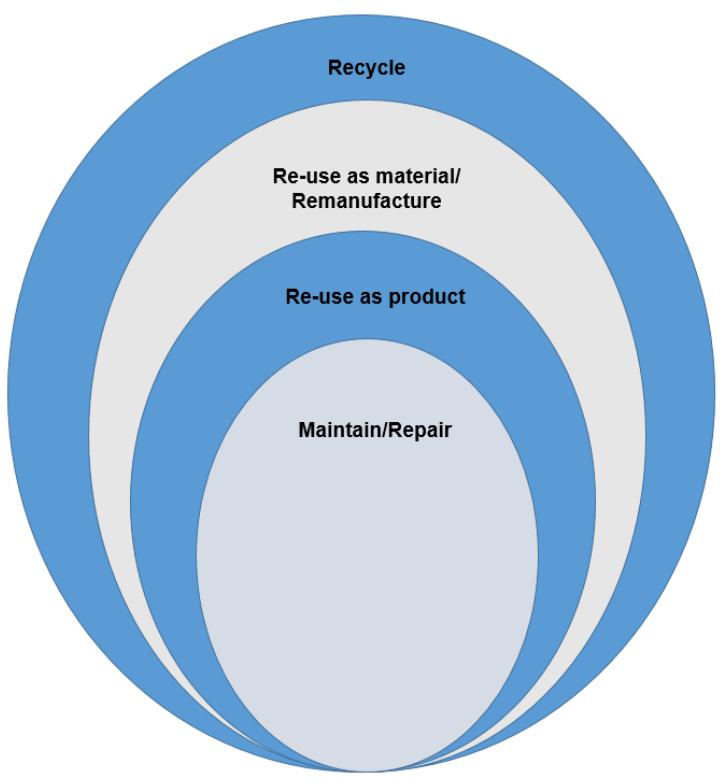

PICBE | 87

Figure 2. Four value cycles of a circular economy

Source: Author's own processing based on Ellen MacArthur Foundation, 2017

In the textile and apparel industry, reuse and recycling (in the form of downcycling) is already well established. For example, in Europe about $15-20 \%$ of disposed textiles are collected (the rest is landfilled or incinerated), whereof about $50 \%$ is downcycled and $50 \%$ is reused, mainly through exporting to developing countries (Textile Recycling Association, 2005).

Textile reuse refers to various means for prolonging the practical service life of textile products by transferring them to new owners (Fortuna and Diyamandoglu, 2017), with or without prior modification. Reuse means any operation by which products or components that are not waste are used again for the same purpose for which they were conceived; preparing for reuse means checking, cleaning or repairing recovery operations, by which products or components of products that have become waste are prepared so that they can be reused without any other pre-processing reuse (European Commission, 2008). According to Belk (2014), textile reuse can be done through renting, trading, swapping, borrowing and inheriting, facilitated by, for example, second hand shops, flea markets, garage sales, online marketplaces, charities and clothing libraries. In the academic literature, various forms of reuse have been conceptualized in terms such as collaborative consumption, product-service systems, commercial sharing systems, and access-based consumption. With regard to reuse (European Commission, 2008), terms such as reconditioning, remanufacturing, repair and are relevant as well. Reuse can happen via a range of product exchange mechanisms: citizen to citizen (online marketplaces, flea markets) (C2C); citizen to charity organizations, reuse businesses (e.g. with drop-off centers for used goods) or (separate) municipal waste collection ('C2B'); social or other enterprises to people with demand for certain reuse products ('B2C'); social enterprises or other reuse businesses to enterprises with demand for reuse products ('B2B') (European Environmental Agency, 2018).

The interest in increased textile reuse and recycling is consistent with the increased attention being given to the circular economy concept in international and national policy. Reuse is specifically addressed in 25 of the 33 waste prevention programs of EU countries 
and is increasingly recognized as a waste prevention measure but national approaches to encourage reuse are, so far implemented as single measures. An overall approach to effectively integrating reuse, in the same manner as recycling is integrated into the waste management system, does not exist (European Environmental Agency, 2018).

In 2018, Romania adopted the National Waste Management Plan (Ministerul Mediului, 2018) aiming to encourage green investments, support initiatives which reward the consumers which reduce, reuse, recycle household waste, collaboration with the public administration authorities to increase the efficiency and the quality of the waste collected, to make it easier to recycle; collaboration with the public authorities and the business sector to improve waste collection systems. It is projected that in 2025 the largest categories of waste generators will be represented by households (table 1).

Table 1. The municipal solid waste composition in Bucharest

\begin{tabular}{ccc}
\hline Type of waste & $\mathbf{2 0 1 4}$ & Projected for 2025 \\
\hline bio-waste & $57,90 \%$ & $55 \%$ \\
\hline paper and cardboard & $11,90 \%$ & $13,50 \%$ \\
\hline plastic & $11,70 \%$ & $10 \%$ \\
\hline other & $6,70 \%$ & $6,80 \%$ \\
\hline glass & $5,10 \%$ & $4,50 \%$ \\
\hline metal & $2,70 \%$ & $3,50 \%$ \\
\hline wood & $1,00 \%$ & $2,70 \%$ \\
\hline textiles & under $1 \%$ & $1,00 \%$
\end{tabular}

Source: The Author's own processing based on the Romanian National Waste Management Plan 2018

According to the literature (Tripa, 2014) clothing waste typically transitions to: apparel where $45 \%$ of clothing is reused, 5\% unusable, $20 \%$ reprocessed into basic fiber content and 30\% recovered textiles (Simple recycling, 2014). Taken in consideration that fashion consumption trends show that today the average person buys $60 \%$ more clothing, and keeps them for half as long (Greenpeace, 2017), attention to the textile waste must be paid as well. Although the Romanian National Waste Management plan projects that textile waste will reach $1 \%$ of the waste generated in Romania by 2025 (table 1) and recognizes reuse as a waste prevention measure, no concrete actions were comprised in the plan. However, some activities in clothing reuse are already developed by the non-governmental sector. Charity organizations are the main entity in charge of the collection of reusable textile products, and these private transactions take place not only via charity organizations but increasingly via venues such as Internet and flea markets, without intermediate actors (Tojo et al., 2012).

\section{Methodology}

The primary goal of this research was to understand the role of social entrepreneurship in clothing reuse practices in Bucharest by gaining concrete knowledge related to the stakeholders of household clothing reuse initiatives practiced in Bucharest, in terms of number and characteristics, moving from identifying current clothing reuse practices and mechanisms of exchange to the type of stakeholders involved: public or private. The research aimed to provide data for two of the four value cycles of circular economy for textiles: maintain/repair and re-use as product (figure 2), and therefore mapping the stakeholders in the circular economy for textiles in Romania.

According to Tojo et al. (2012), the charity organizations are the main entity in charge of collection of reusable textile products and there have been growing interest among private 
consumers to reuse clothes, these private transactions take place not only via charity organizations but increasingly via venues such as Internet and flea markets, without intermediate actors. In Romania, 56\% of social enterprises are non-governmental organizations undertaking some economic activity (Staicu, 2017). Therefore, to some extent NGO's act as social enterprises. The main research question is "Are social entrepreneurs the main driver of textile waste prevention through clothing reuse activities in Bucharest?". To validate the research question, two assumptions were formulated: practices.

A1: In Bucharest, both private and public stakeholders are involved in clothing reuse

A2: In Bucharest, charities acting as social enterprises are the main stakeholders in clothing reuse practices.

According to Bhardwaj and Fairhurst (2009), fashion is considered to be a temporary cyclical phenomenon. Conventional content analysis is generally used with a study design whose aim is to describe a phenomenon. This type of design is usually appropriate when an existing theory or research literature on a phenomenon is limited and goes beyond merely counting words to examining language intensely for the purpose of classifying large amounts of text into an efficient number of categories that represent similar meanings (Weber, 1990). Researchers avoid using preconceived categories instead of allowing the categories and names for categories to flow from the data (Kondracki \& Wellman, 2002). According to this methodology, the framework in figure 3 was developed.

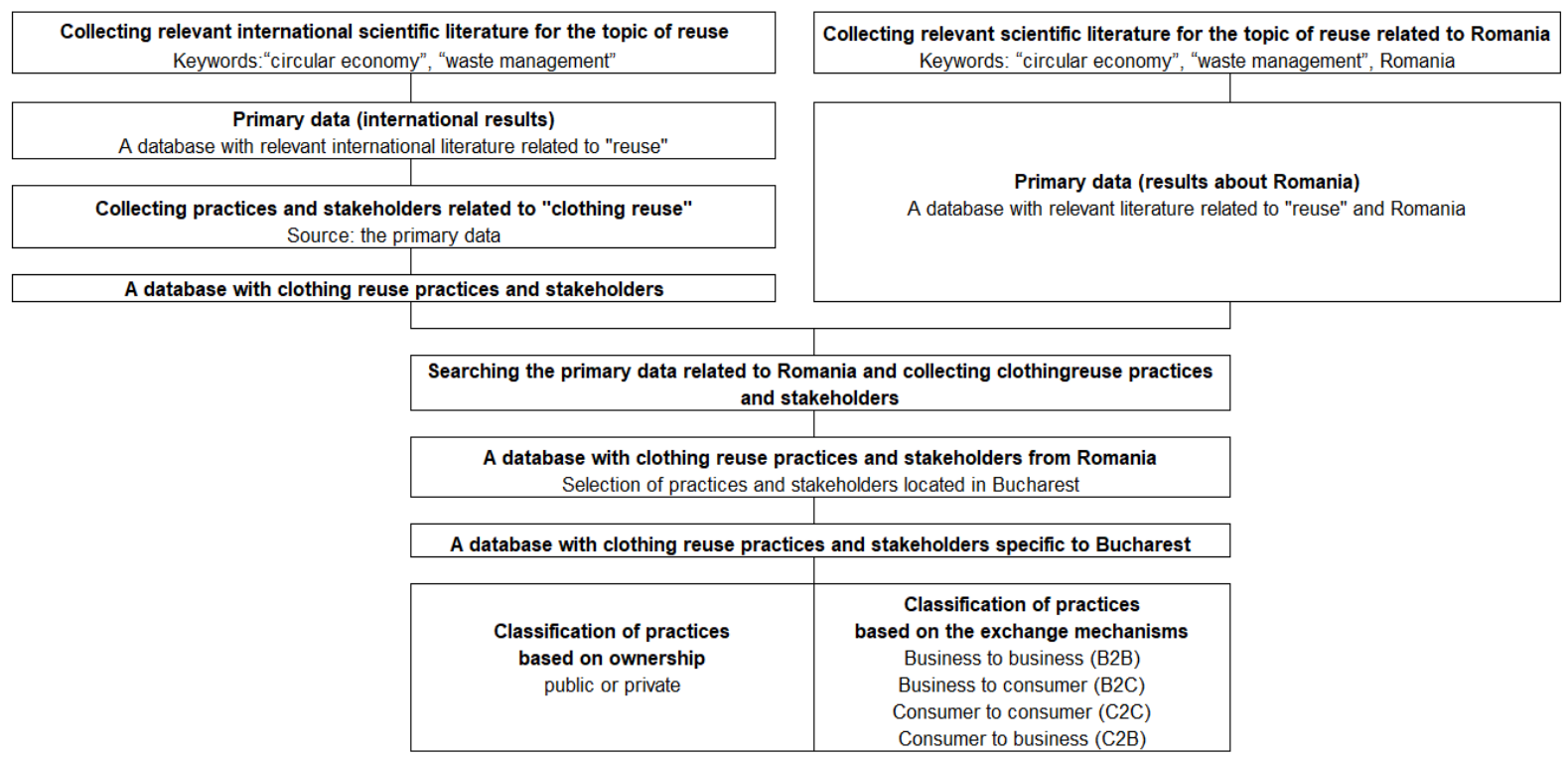

Figure 3. The methodology developed for the research

Source: The Author's own processing

The content analysis was performed using the qualitative research software NVivo. Priority was given to the body of scientific literature published between 2013 and 2018 published in ScienceDirect, SAGE Journals, Wiley Online Library, Springer Link Library, ProQuest; reports published by various stakeholders in the circular economy (European Commission, Ellen MacArthur Foundation); an open Web and targeted search in web articles and blogs in order to also capture reuse practices not captured yet in the scientific literature.

\section{Results and discussions}

Research in scientific databases returned a preliminary database with 61 papers and reports related to "waste management" and "circular economy". Secondly, a query done with NVivo with the keyword "reuse" returned 2 categories of associated words (table 2). 
Table 2. Keywords related to clothing reuse practices and stakeholders

\begin{tabular}{ll}
\hline Clothing reuse practices & Clothing reuse facilities/businesses \\
\hline clothing repairing & second hand shops \\
clothing reconditioning/ refurbishment & flea markets \\
clothing remanufacturing & garage sales \\
upgrading, disassembly, recovery of clothing & online marketplaces \\
clothing renting, trading, swapping, borrowing & charity organizations \\
selling used clothing & clothing libraries \\
donating used clothing & clothing reuse centers \\
secondary lifetime & drop-off centers \\
old clothes & municipal reuse center \\
secondhand clothing & private reuse center \\
recirculation & online platforms \\
& repair shops, centers, hubs, networks \\
& service centers \\
charities to repair and reuse \\
markets for used clothes \\
& reuse enterprise \\
& reuse market \\
& reuse superstores \\
& Salvation Army \\
& social enterprises \\
\hline & Source: Author's own processing
\end{tabular}

Third, a preliminary database of papers and reports related to "waste management" and "circular economy" about Romania, returned 10 papers from 2014 to 2018. Using the keywords in table 2 and NVivo software, a research was performed on the preliminary database focused on Romania. Apart from the scientific literature analysis, a Web literature review was performed: each keyword from table 3 was translated into the Romanian language and Google engine search was performed using each of the keywords and the word "Bucharest" to identify only clothing reuse practices and facilities located in Bucharest.

Table 3. Keywords related to clothing reuse practices and stakeholders used in Google search in Romanian language

\begin{tabular}{ll}
\hline Clothing reuse practices & Clothing reuse facilities/businesses \\
\hline reparații îmbrăcăminte & magazine second hand \\
recondiționare îmbrăcăminte & piață de vechituri \\
confecționare îmbrăcăminte & vânzare de vechituri \\
închiriere, schimbare, împrumut îmbrăcăminte & piețe online \\
vânzarea de haine folosite/uzate/second-hand & organizații de caritate \\
donarea îmbrăcămintei folosite & biblioteci de îmbrăcăminte \\
haine vechi & centrele de reutilizare \\
haine second-hand & centre de colectare \\
refolosire a hainelor & platforme online \\
& centre de reparații, hub-uri, rețele de \\
& servicii de reparații \\
& supermarket social \\
& organizația Armata Salvării \\
& întreprinderi sociale
\end{tabular}

Source: Author's own processing

The two queries returned the following results:

(1) The clothing reuse practices in Bucharest are divided into two categories: preparing for reuse and reuse (table 3 ). 
Table 3. Type of activities related to textile waste prevention through clothing reuse in Bucharest

\begin{tabular}{|c|c|c|c|c|c|c|}
\hline Preparing for reuse & \multicolumn{6}{|c|}{ Reuse } \\
\hline Repair shops & $\begin{array}{c}\text { Flea market } \\
\text { /Garage Sale } \\
\text { /Yard Sale }\end{array}$ & $\begin{array}{c}\text { Second hand } \\
\text { shops }\end{array}$ & $\begin{array}{c}\text { Online } \\
\text { marketplaces }\end{array}$ & $\begin{array}{l}\text { Charities } \\
\text { (where you can } \\
\text { donate items, and } \\
\text { they place it to } \\
\text { people in need) }\end{array}$ & $\begin{array}{l}\text { Online groups } \\
\text { for clothing } \\
\text { exchange }\end{array}$ & $\begin{array}{l}\text { City Hall } \\
\text { District } 1\end{array}$ \\
\hline
\end{tabular}

Source: Author's own processing

The majority of clothing reuse initiatives are related to reuse and less on preparing for reuse, typically done in repair shops.

(2) The ownership is divided into public and private, according to the type of stakeholder who initiated the activity. $86,71 \%$ of the clothing reuse initiatives are private, either owned by NGO's or by companies.

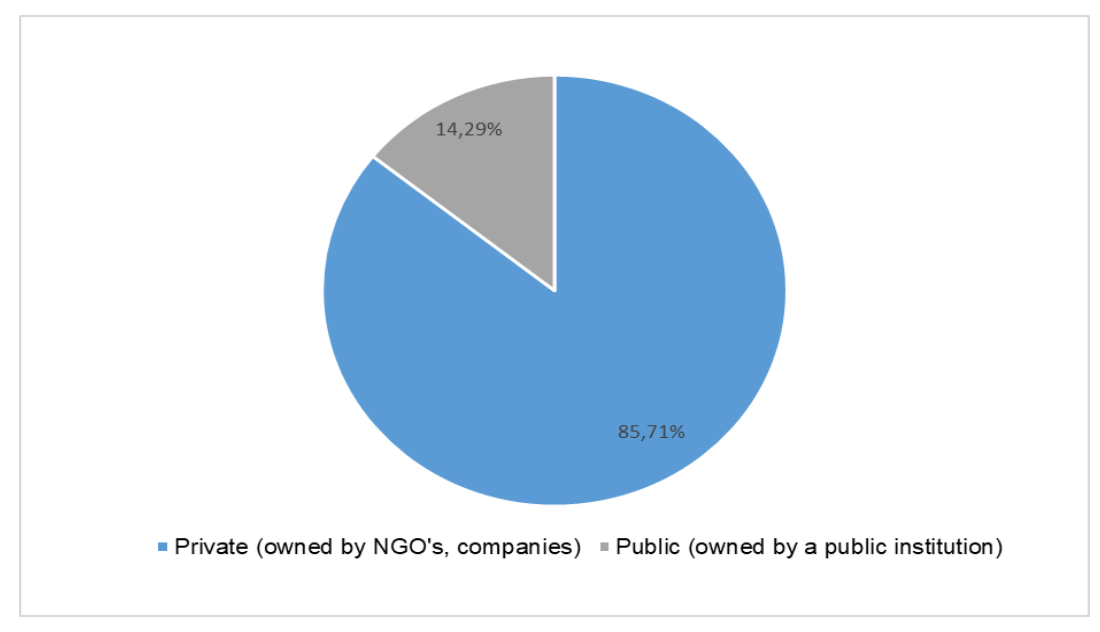

Figure 4. Type of clothing reuse activities according to ownership

Source: Author's own processing

(3) The private clothing reuse initiatives are focused both on preparing for reuse and reuse, with more activities focused on reuse.

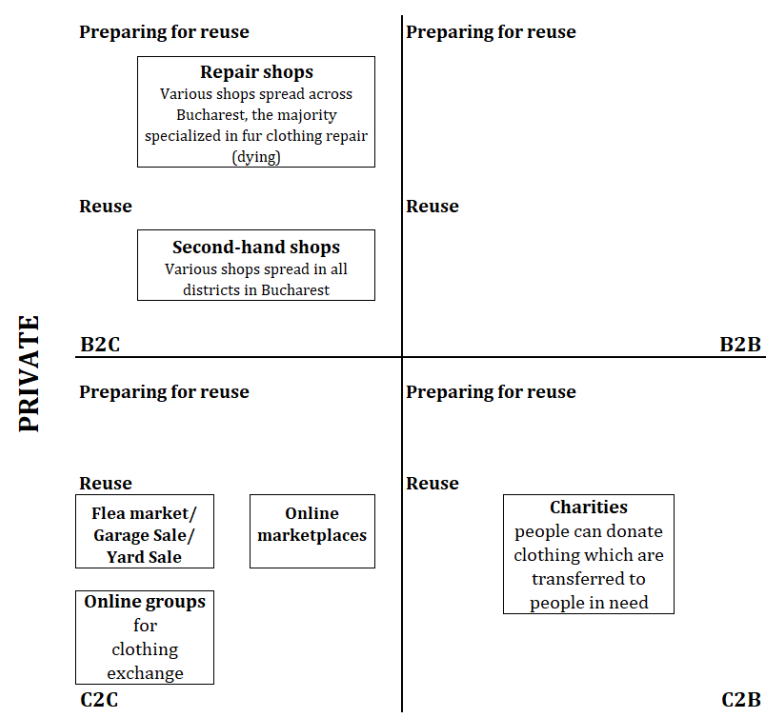

Figure 5. Private clothing reuse practices developed by companies and charities

Source: Author's own processing 
(4) In Bucharest, there is only one public clothing reuse initiative and the owner is the City Hall district 1 (figure 6).

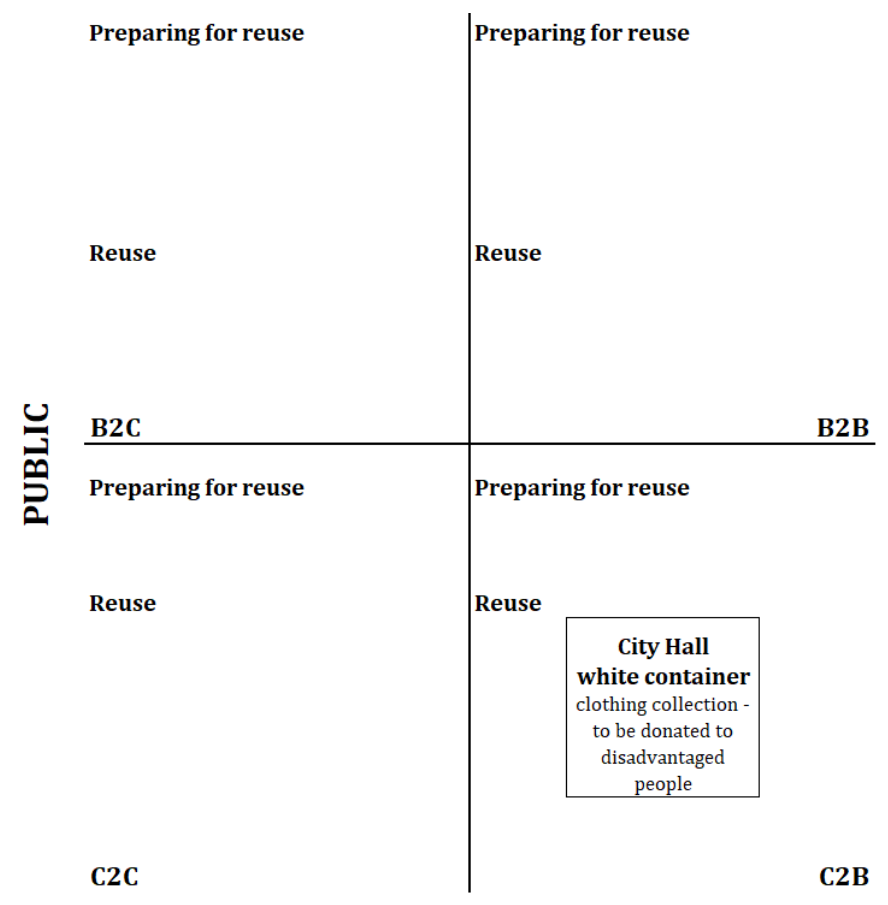

PICBE | 92

Figure 6. Clothing reuse practices developed by public institutions

Source: Author's own processing

Figures 5 and 6 show a low level of reuse practices developed by the public authorities compared to private initiatives.

(5) NGO's have the most numerous initiatives related to clothing reuse (figure 7).

It is difficult to determine the number of second-hand shops in Bucharest because the literature and the Web does mention them nominally.

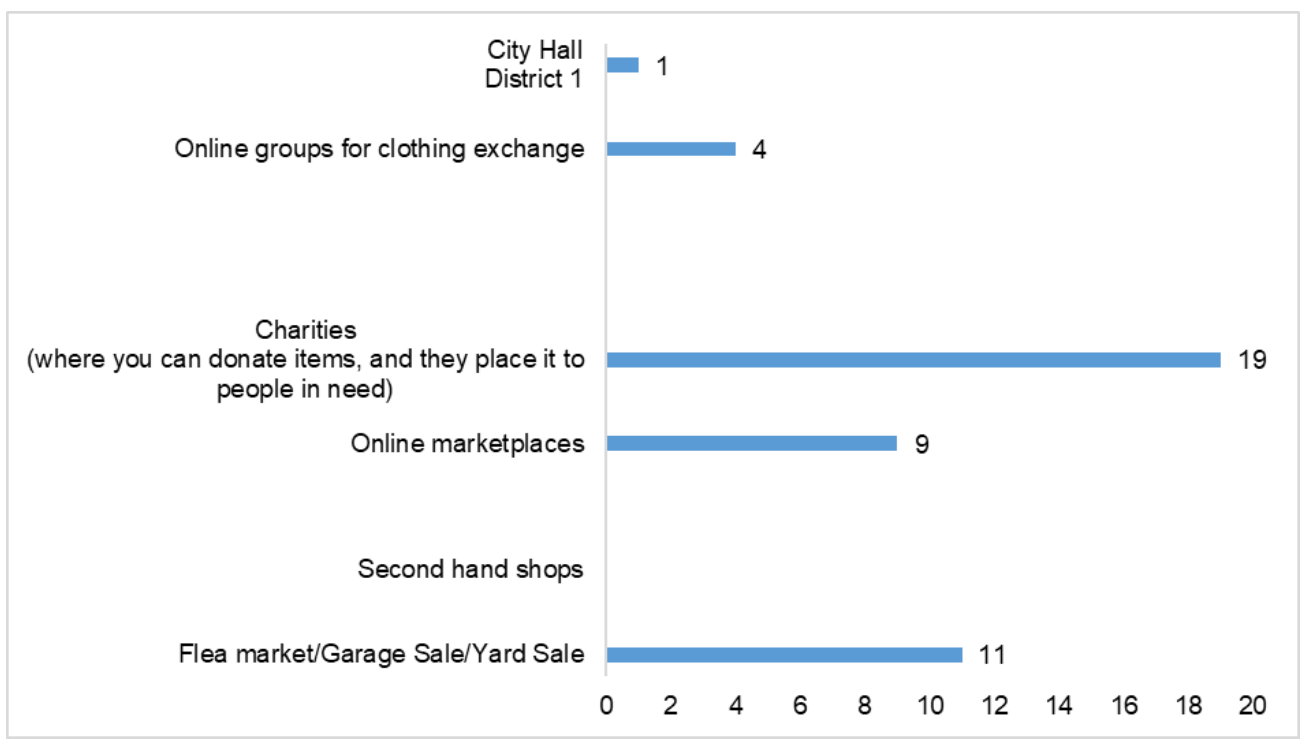

Figure 7. Type of clothing reuse activities privately owned

Source: Author's own processing 
(2) The research identified the existence of three of the four product exchange mechanisms in Bucharest clothing reuse practices (table 4): B2C - Business to consumer, C2C Consumer to consumer, C2B: Consumer to business.

Table 4. Type of exchange mechanisms in clothing reuse practices in Bucharest

\begin{tabular}{ccc}
\hline Ownership & Type of mechanism & Category of business \\
\hline $\begin{array}{c}\text { Private } \\
\text { B2C }\end{array}$ & Repair shops \\
C2C & Flea market/Garage Sale/Yard \\
Sale
\end{tabular}

In the case of charities, the mechanism of exchange is considered consumer to business because the textiles as discarded by an individual consumer in a location run by a charity. However, most often charities, reuse the clothing by offering them to disadvantaged people who need them for day to day life or when seeking a job (Forbes, 2016), or exporting to developing countries (Textile Recycling Association, 2005). Textile waste produced by households can be turned for reuse via $\mathrm{C} 2 \mathrm{C}, \mathrm{C} 2 \mathrm{~B}$ and $\mathrm{B} 2 \mathrm{C}$ mechanism, all functional in Bucharest, via private ownership. Most developed clothing reuse initiatives are C2C (figure 8).

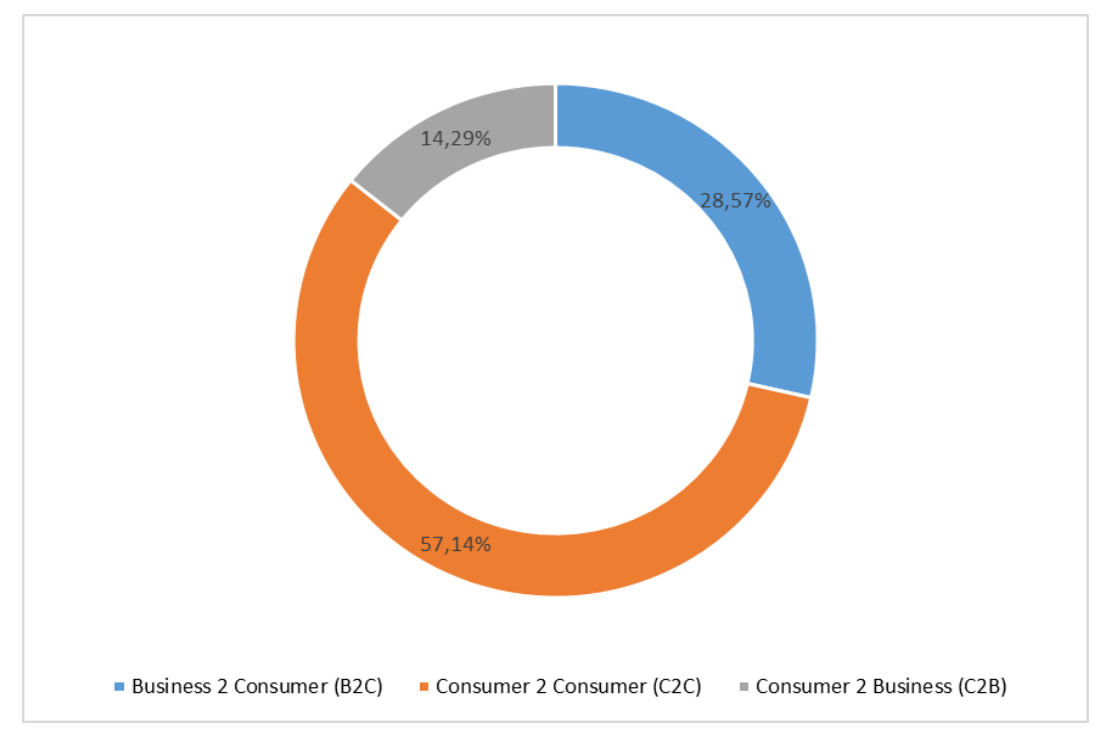

Figure 8. Mechanisms of exchange in clothing reuse activities privately owned

Source: Author's own processing

(3) Finally, the researched offered a representation of the Bucharest stakeholders in the circular economy for textiles, involved in preparing for reuse and reuse value cycles (table 5). 
The findings reveal that the clothing reuse practices developed in Bucharest are owned by both private and public stakeholders.

Table 5. Clothing reuse practices in Bucharest

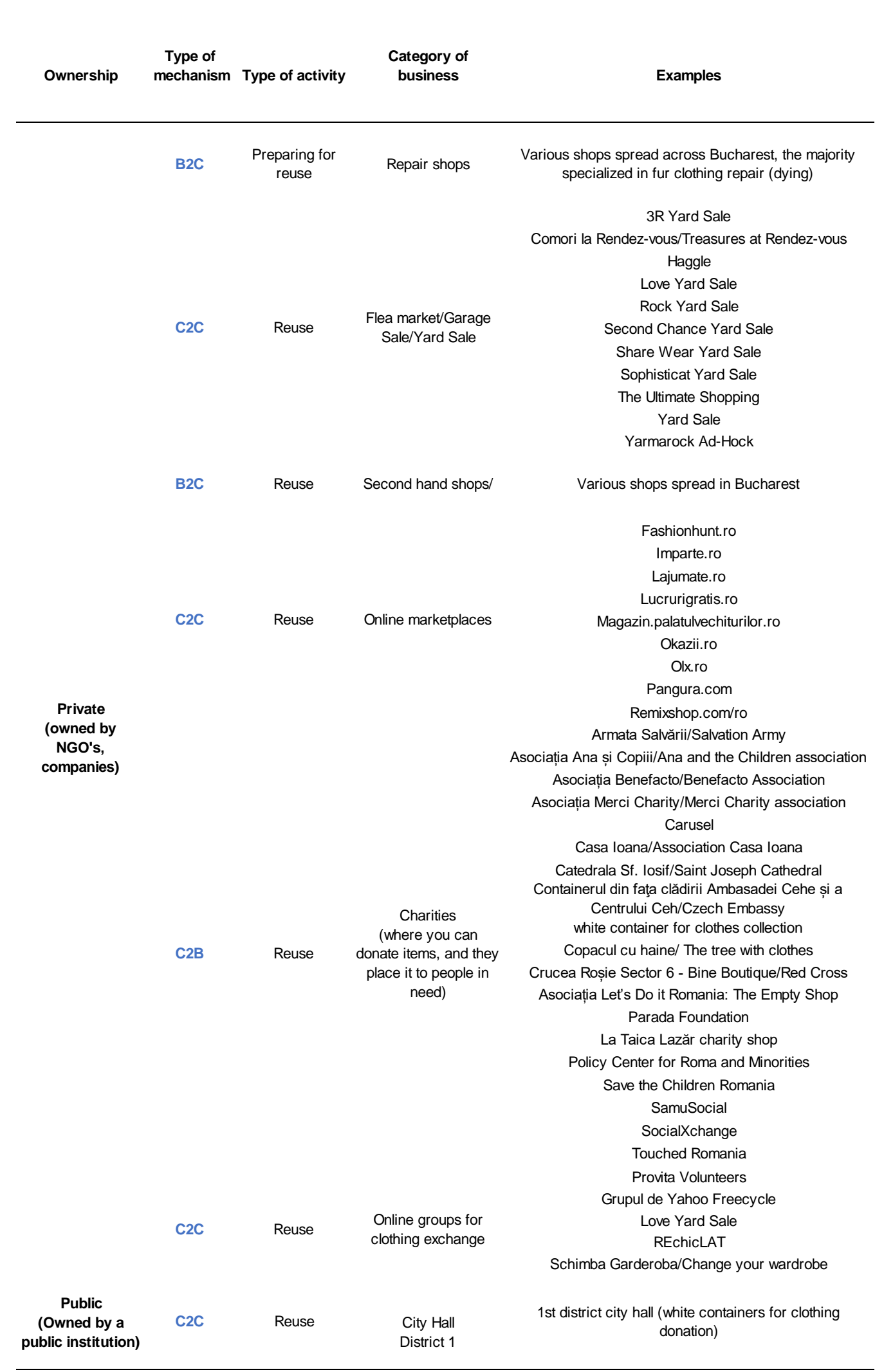

PICBE | 94

Source: Author's own processing 
Private stakeholders are split in divided into categories: repair shops, second hand shops, flea markets/garage sale/yard sale, online marketplaces, charities, and online groups for clothing exchange. Public stakeholders have only one representative: the $1^{\text {st }}$ district city hall. These results validate the first assumption formulated: "In Bucharest, both private and public stakeholders developed clothing reuse practices". According to figure 7, most of the reuse activities are developed by charities (19), a result which validates the second assumption that "In Bucharest, charities are the main developer of existing clothing reuse practices". According to the literature, in Romania charities undertaking some economic activity are perceived as being social enterprises (Staicu, 2017). To this extend, we may conclude that in Bucharest, existing clothing reuse practices are mainly developed by social enterprises."

These results contribute to modeling the circular business ecosystem for textiles in Romania, by mapping the stakeholders in preparing reuse and reuse activities, two of the four value cycles in the circular economy (figure 9).

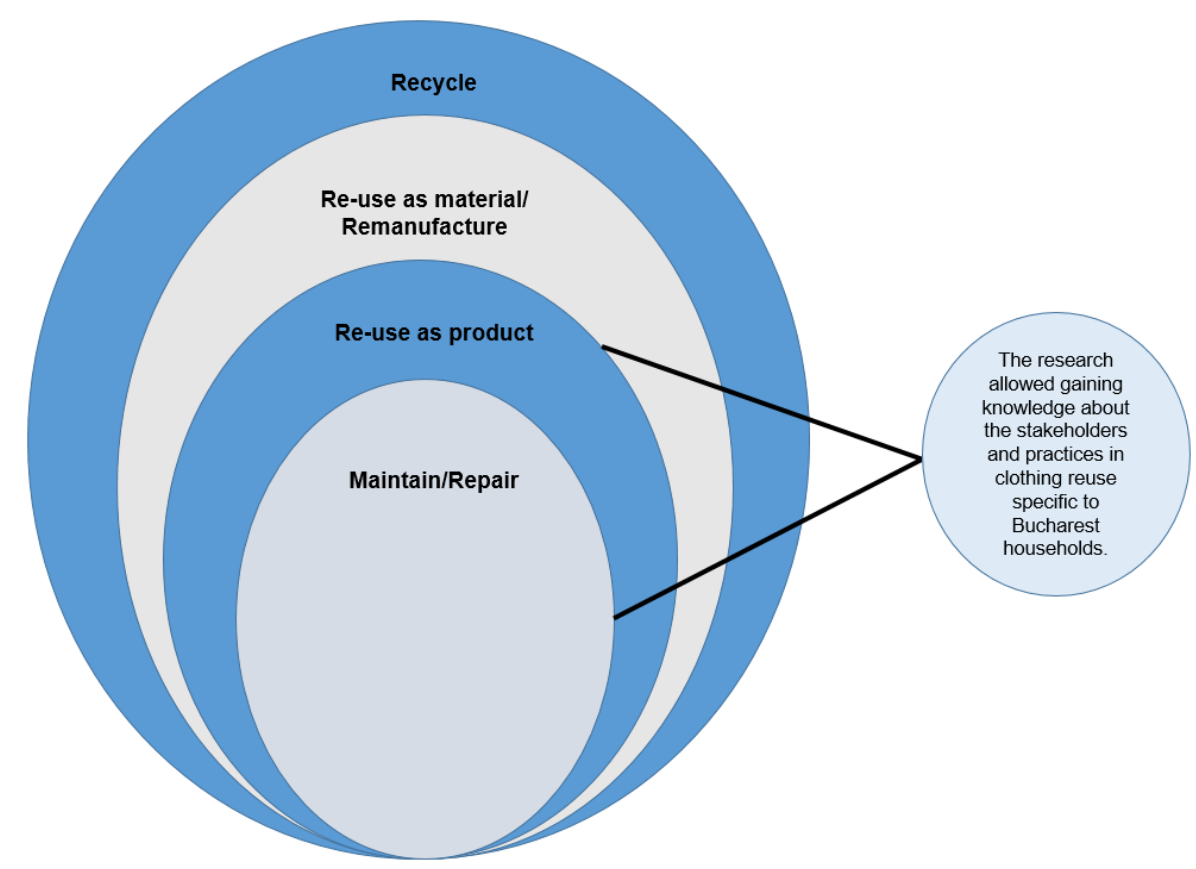

Figure 9. The research contribution to the circular business economy for textile for Romania

Source: Author's own processing

\section{Conclusions, limitations and recommendations}

The primary goal of this research was to understand the role of social entrepreneurship in clothing reuse practices in Bucharest by gaining concrete knowledge related to the stakeholders in household clothing reuse initiatives practiced in Bucharest, in terms of number and characteristics, moving from identifying current clothing reuse practices and mechanisms of exchange to the type of stakeholders involved: public or private. Bucharest was chosen for this research because it has the largest number of households in Romania. To achieve the goal, the content analysis qualitative research method was used.

The findings revealed that the clothing reuse practices developed in Bucharest are owned by both private and public stakeholders. Private stakeholders are divided in six categories: repair shops, second hand shops, flea markets/garage sale/yard sale, online marketplaces, charities, and online groups for clothing exchange. Public stakeholders have only one representative: the first district city hall. This disproportion shows a low level of reuse practices developed by the public authorities. Most of the reuse activities are developed 
by charities (19), which to some extend act as social enterprises, given the social and environmental impact. The research contributes to modelling the circular business ecosystem in Romania, by providing data about two of the four value cycles of circular economy for textiles: maintain/repair and re-use as product (figure 2). This model can be replicated to identify stakeholders in clothing reuse in other Romanian cities and deepen the analysis on the circular economy model for textiles in Romania.

This study comes with some limitations. The research analyzed a small database of scientific literature referring to Romania: 10 papers and reports. However, a thorough Web research was performed. The majority of charities, flea markets and online markets have a visible presence online because this is the space where they promote their activities and attract buyers or donors. The same statement cannot be done about repair shops and second-hand shop because most of their activity is based offline, in stores. Therefore, it was difficult to identify all of them individually, by name.

Furthermore, the research methodology was based on a qualitative method and it is recommended that quantitative methods to be used to explore if there is a shift in textile waste prevention through clothing reuse practices once the Romanian government starts the implementation of the National Waste Management Plan published in 2018. Therefore, an iteration of this process is needed by the end of next year to understand if changes in practices and behaviors have happened. More attention needs to be paid to social entrepreneurs with initiatives related to clothing reuse and assess the needs for scaling up their actions and increase their visibility.

The researcher should share her context-specific knowledge on national and international levels and contribute to spreading indigenous knowledge combined with practices internationally, as this subject is of current interest in the EU Member States.

\section{References}

Belk, R. (2014). You are what you can access: sharing and collaborative consumption online. Journal of Business Research, 67 (8), 1595-1600.

Bhardwaj, V., Fairhurst, A. (2009). Fast fashion: Response to changes in the fashion industry. The International Review of Retail Distribution and Consumer Research Distribution and Consumer Research, 20(1), 165-173, DOI: $10.1080 / 09593960903498300$.

Bryman, A. (2012). Social Research Methods. Oxford: Oxford University Press.

Burns, L. (2016, June 7). Tackling textile waste. Retrieved from http://www.responsibleglobalfashion.com/blog/2016/7/tackling-textile-waste.

Claudio, L. (2007). Waste couture: Environmental impact of the clothing industry. Environmental Health Perspectives, 115, 449-454.

Cuc, S., Tripa, S. (2014). Fast fashion and second hand clothes between ecological concerns and global business. Annals of the University of Oradea Fascicle of textiles, leatherwork. Retrieved from https://www.researchgate.net/publication/304626238_FAST_FASHION_AND_SECO ND_HAND_CLOTHES_BETWEEN_ECOLOGICAL_CONCERNS_AND_GLOBA L_BUSINESS.

Denscombe, M. (2010). The Good Research Guide. Maidenhead: Open University Press.

Durham, E., Hewitt, A., Bell, R., Russell, S. (2015). Technical Design for Recycling of Clothing. Woodhead Publishing.

Ellen MacArthur Foundation. (2017, November 28). A new textiles economy: Redesigning fashion's Future. Retrieved from ttp://www.ellenmacarthurfoundation.org/publications (accessed on October 1st, 2018).

EURATEX. (2017). Key Figures 2017 - The EU-28 Textile and Clothing Industry in the 
year 2017. Retrieved from http://euratex.eu/press/key-data/

European Commission. (2015, December 2). Closing the loop - An EU action plan for the

Circular Economy. Retrieved from https://eur-lex.europa.eu/legal-

content/EN/TXT/?uri=CELEX:52015DC0614.

European Commission. (2013, December 28). General Union Environment Action

Programme to 2020 'Living well, within the limits of our planet. Retrieved from

https://eur-lex.europa.eu/legal-content/EN/TXT/?uri=celex\%3A32013D1386.

PICBE | 97

European Commission. (2011, September 20). Roadmap to a Resource Efficient Europe.

Retrieved from https://eur-lex.europa.eu/legal-

content/EN/TXT/?uri=CELEX:52011DC0571.

European Commission. (2010). Being wise with waste: the EU's approach to waste

Management. Retrieved from

ec.europa.eu/environment/waste/pdf/WASTE\%20BROCHURE.pdf.

European Commission. (2008, November 22). Directive 2008/98/EC of the European

Parliament and of the Council of 19 November 2008 on waste and repealing certain

Directives. Retrieved from https://eur-lex.europa.eu/legal-

content/EN/TXT/?uri=celex\%3A32008L0098.

Farrant, L., Olsen, S.I., Wangel, A. (2010). Environmental benefits from reusing clothes. International Journal Life Cycle Assess, 15, 726-736, DOI 10.1007/s11367-010-0197$\mathrm{y}$.

Fontell, P. and Heikkilä P. (2017, February 20). Model of circular business ecosystem for textiles. Retrived at http://ethica.fi/en/relooping-fashion-we-are-making-fashioncircular/

Forbes. (2016, December 9). 4 ways to donate to a charity without writing a check. Retrieved from https://www.forbes.com/sites/nextavenue/2016/12/09/4-ways-to-donate-tocharity-without-writing-a-check/

Fortuna, L.M, Diyamandoglu, V. (2017). Optimization of greenhouse gas emissions in second-hand consumer product recovery through reuse platforms. Waste Management, 66, 178-189.

Goldbach, M., Seuring, S., Back, S. (2003). Co-ordinating Sustainable Cotton Chains for the Mass Market: The Case of the German Mail-Order Business OTTO.

Greener Management International, 43, 65-78.

Greenpeace. (2016, November 24). Greenpeace calls timeout for fast fashion. Retrieved from https://www.greenpeace.org/international/press-release/7566/black-friday-greenpeacecalls-timeout-for-fast-fashion/

Koszewska, M. (2011). The ecological and ethical consumption development prospects in Poland compared with the Western European countries. Comparative Economic Research, 14, 101-123.

Lenzing. (2017). The Global Fiber Market in 2016. Retrieved from https://www.lenzing.com/fileadmin/content/PDF/07_Finanzen/Geschaeftsberichte/EN/ GB_2016_EN.pdf

Leonas, K.K. (2017). The Use of Recycled Fibers in Fashion and Home Products. Textiles and Clothing Sustainability, Springer, DOI: 10.1007/978-981-10-2146-6_2

Kondracki, N. L., Wellman, N. S. (2002). Content analysis: Review of methods and their applications in nutrition education. Journal of Nutrition Education and Behavior, $34,224-230$.

Koszewska, K. (2018). Circular economy - Challenges for the textile and clothing Industry. AUTEX Research Journal, DOI: 10.1515/aut-2018-0023.

Martin, M. (2013). Making Impact Investible. Impact Economy Working Papers, 4, Retrieved from http://dx.doi.org/10.2139/ssrn.2272553. 
Ministerul Mediului. (2018). Hotărâre privind aprobarea planului naţional de gestionare a deșeurilo. Monitorul Oficial al României, partea 1, 186 (11bis), 1-410. Retrieved from http://www.mmediu.ro/categorie/planul-national-de-gestionare-adeseurilor-pngd/239 (accessed on December 2, 2018).

Onwuegbuzie, A. J., Leech, N. L., \& Collins, K. M. T. (2012). Qualitative analysis techniques for the review of the literature. The Qualitative Report, 17(28), 1-28.

Păceșilă, M., Ciocoiu, C. N., Colesca, S. E., Burcea, Ș. G. (2016). Current trends in WEEE management in Romania. Theoretical and Empirical Researchers in Urban Management, 11(4), 46-59.

Pipatti, R., Sharma, C., Yamada, M. (2006). Waste Generation, Composition and Management Data, 2006 IPCC Guidelines for National Greenhouse Gas Inventories. Retrieved from http://www.ipcc-nggip.iges.or.jp/public/2006gl/pdf/5_Volume5/V5_2_ Ch2_Waste_Data.pdf.

Remy, N., Speelman, E., Swartz, S. (2016, October). Style that's sustainable: A new fastfashion formula. Retrieved from https://www.mckinsey.com/businessfunctions/sustainability-and-resource-productivity/our-insights/style-thats-sustainablea-new-fast-fashion-formula.

Resta, B., Gaiardelli, P., Pinto, R., Dotti, S. (2016). Enhancing environmental management in the textile sector: An organisational-life cycle assessment approach. Journal of Cleaner Production, 135, 620-632.

Sandin, G., Peters, G.M. (2018). Environmental impact of textile reuse and recycling - A Review. Journal of Cleaner Production, 184, 353-365.

Sandin, G., Peters, G.M., Svanström, M. (2015). Using the planetary boundaries framework for setting impact-reduction targets in LCA contexts, The International Journal of Life Cycle Assessment, Springer Berlin Heidelberg, 20 (12), 1684-1700, Retrieved from https://doi.org/10.1007/s11367-015-0984-6.

Shen, L., Worrell E., Patel, M.K. (2010). Environmental impact assessment of man-made cellulose fibres. Resour. Conserv. Recycl., 55, 260-274.

Smith, P., Baille, J., McHattie, L. (2017). Sustainable Design Futures: An open design vision for the circular economy in fashion and textiles. The Design Journal, 20, Retrieved from doi: 10.1080/14606925.2017.1352712

Staicu, D. (2017). Policy framework and legal forms of social enterprise in Central and Eastern Europe, Proceedings of the International Conference on Business Excellence, De Gruyter Open, 11(1), 875-883. Retrieved from https://doi.org/10.1515/picbe-2017-0093.

Textile Recycling Association. (2005, June). OUVERTES Project - Report by Textile Reuse and Recycling Players on the Status of the Industry in Europe.

Retrieved from http://www.textilerecycling.org.uk/downloads/Report_Ouvertes_Project_June2005\%5B1\%5D.pdf.

The Council of the European Union. (2018, May 22). Waste management and recycling: Council adopts new rules. Retrieved from https://www.consilium.europa.eu/en/press/press-releases/2018/05/22/wastemanagement-and-recycling-council-adopts-new-rules/\#

The Fiber Year. (2015, April). World survey on Textiles and nonwovens. Retrieved from https://www.textilemedia.com/assets/Uploads/TFY15-sample-pages.pdf.

Tojo, N., Kogg, B., Kiørboe, N., Kjær, B., Aalto, K. (2012, September 27). Prevention of Textile Waste Material flows of textiles in three Nordic countries and suggestions on policy instruments. Retrieved from norden.divaportal.org/smash/get/diva2.../FULLTEXT01.pdf.

Van Ewijk, S., Stegemann, J.A. (2016). Limitations of the waste hierarchy for achieving 
absolute reductions in material throughput. Journal of Cleaner Production, 132, $122-$ 128.

Wells, P. (2008). Alternative business models for a sustainable automotive industry. A Tukker, M Charter, C Vezzoli, E St $\phi$, \& M Andersen (Eds.), System innovation for sustainability. Sheffield: Greenleaf Publishing.

Yin, R. K. (2014). Case Study Research: Design and Methods. Los Angeles: SAGE. 